\title{
LEUKOCYTE DEBRANCHING ENZYME IN GLYCOGEN STORAGE DISEASE
}

\author{
By HIBBARD E. WILLIAMS, ESTHER M. KENDIG, AND JAMES B. FIELD \\ (From the Clinical Endocrinology Branch, National Institute of Arthritis and Metabolic \\ Diseases, Bethesda, Md.)
}

(Submitted for publication August 6, 1962 ; accepted January 17, 1963)

In recent years the classification of glycogen storage disease has been based on the demonstration of a specific enzyme defect for each type (14). Type I, glycogenosis or von Gierke's disease, results from the lack of glucose 6-phosphatase (1). Type II, or Pompe's disease, is characterized clinically by the severity of the disease with cardiovascular complications causing death usually before the eighth month of life (5). Recently Hers has reported that a deficiency of a specific $\alpha$-glucosidase exists in this condition (3). Type III, or limit dextrinosis, results from a lack of hepatic debranching enzyme or amylo-1-6-glucosidase (6). Type IV is presumed to be due to lack of branching enzyme, although no definite enzymatic assays have been performed to prove this (7). In some classifications, Type $\mathrm{V}$ is divided into two subgroups-those with lack of muscle phosphorylase $(\mathrm{Vb})(8,9)$, and those with a deficiency in hepatic phosphorylase (Va) (10). Others have preferred categorizing patients with muscle phosphorylase deficiency as Type $\mathrm{V}$ and those patients with hepatic phosphorylase deficiency as Type VI (4).

In many of these types the specific diagnosis can only be made by demonstration of the enzymatic defect in tissue obtained by liver biopsy. In view of the demonstration of low leukocyte phosphorylase in hepatic phosphorylase-deficient glycogen storage disease by Williams and Field (11) and because of the desirability of using leukocytes rather than liver tissue in establishing the specific enzymatic defect in glycogen storage disease, a method of assay for debranching enzyme has been applied to leukocytes. The results of this assay using leukocytes from patients with glycogen storage disease, their relatives, and a group of control subjects forms the basis of this report.

\section{MATERIALS AND METHODS}

A. Control subjects. All subjects studied were patients at the Clinical Center of the National Institutes of Health. None of the patients, except L.B., had a history of liver disease nor was hepatomegaly found on physical examination. Patient L.B. was a 3-year-old boy with slight hepatomegaly of unknown cause. The control subjects used for the determination of red blood cell glycogen ranged in age from 3 years to 45 years.

B. Patient with Type III glycogenosis and her family. The patient S.P. was a 3-year-old female child with hepatomegaly, retarded growth, and a history of frequent infections. She had had blood glucose determinations recorded as low as $19 \mathrm{mg}$ per $100 \mathrm{ml}$, but generally fasting blood glucoses ranged between 40 to $50 \mathrm{mg}$ per $100 \mathrm{ml}$. Serum cholesterol was $347 \mathrm{mg}$ per $100 \mathrm{ml}$, and bleeding studies and uric acid were normal. The following liver function studies were done: bilirubin, $0.2 \mathrm{mg}$ per $100 \mathrm{ml}$; thymol turbidity, $12 \mathrm{U}$; cephalin flocculation, negative; alkaline phosphatase, 32 King-Armstrong $U$; total protein, $7.7 \mathrm{~g}$ per $100 \mathrm{ml}$; albumin, $4.8 \mathrm{~g}$ per $100 \mathrm{ml}$; globulin, $2.9 \mathrm{~g}$ per $100 \mathrm{ml}$; and serum glutamic-oxaloacetic transaminase, 500 to $600 \mathrm{U}$. She had had two liver biopsies performed at another hospital, both showing elevated liver glycogen and normal glucose 6-phosphatase and phosphorylase activity. The last biopsy revealed a low level of debranching enzyme activity, 1 approximately $40 \%$ of normal. In addition, the liver glycogen isolated from the biopsy specimen had relatively short outer chains. Phosphorylase treatment caused degradation of $13 \%$ of the glycogen, whereas with normal glycogen $35 \%$ is degraded. Debranching enzyme activity was not performed on the first biopsy.

The members of the family included the mother, age 29 , father, age 29, a 5-year-old sister, and a 16-month-old brother. There was no history of liver disease or hepatomegaly in any of the family members, and physical examination was normal in all. Fasting blood glucose, cholesterol, uric acid, and liver function studies including transaminases were within normal limits in all members of the family. Intramuscular glucagon produced a normal rise in blood glucose in all, as did intravenous galactose.

1 Performed by Dr. Barbara Illingworth Brown, Washington University, St. Louis, Mo. 
C. Patients with glycogen storage disease other than Type III. Patient D. D. had glycogen storage disease clinically of the von Gierke's type although glucose 6phosphatase, phosphorylase, and debranching enzyme were normal on liver biopsy. Patient S. T. was a 9month-old infant with hepatomegaly, hypoglycemia, hyperlipidemia, and elevated liver glycogen and a flat response in her blood glucose to intramuscular glucagon. No enzyme studies had been done on her liver biopsy specimen, however. Patients R. A. and J. A. were brothers with hepatic phosphorylase-deficient glycogen storage disease (11).

D. Leukocyte studies. Blood, 10 to $20 \mathrm{ml}$, was drawn by venipuncture from patients in the fasting state. Leukocytes were obtained by the fibrinogen sedimentation technique (12) using 3\% bovine fibrinogen in KrebsRinger bicarbonate buffer ( $\mathrm{pH} 7.4)$. The total number of leukocytes was estimated in the supernatant fluid after a 15-minute sedimentation at room temperature. After centrifugation of the supernatant fluid at $755 \mathrm{~g}$ for 10 minutes, the button of cells, which contained approximately a $1: 1$ ratio of leukocytes to erythrocytes, was suspended in 0.5 to $1.0 \mathrm{ml}$ of distilled water. After sonication of the cells in a $10-\mathrm{kc}$ ultrasonic oscillator for 5 minutes, debranching enzyme activity was measured by the method of Hers (10). A $0.15-\mathrm{ml}$ sample of the sonicate was added to centrifuge tubes containing $0.075 \mathrm{ml}$ $\mathrm{C}^{14}$-glucose $(20 \mu \mathrm{c}$ per $\mathrm{ml}, 1,500,000 \mathrm{cpm}, 0.18 \mathrm{mg}$ glucose), $0.2 \mathrm{ml} 20 \%$ glycogen, $0.05 \mathrm{ml} 0.1 \mathrm{M}$ phosphate buffer at $\mathrm{pH} 7.4$, and $0.05 \mathrm{ml} 0.5 \mathrm{M} \mathrm{NaF}$; incubation was carried out for 2 hours at $37^{\circ} \mathrm{C}$. The reaction was stopped by the addition of $6.5 \mathrm{ml}$ of a solution containing $0.5 \mathrm{ml} 1.5 \mathrm{M}$ trichloracetic acid, $2 \mathrm{ml}$ distilled water, and $4 \mathrm{ml} \mathrm{100 \%}$ ethanol. The tubes were centrifuged at $755 \mathrm{~g}$ for 10 minutes and the supernatant fluid discarded. The precipitate was then redissolved in $2 \mathrm{ml}$ distilled water, and reprecipitation was carried out with $2.4 \mathrm{ml} 100 \%$ alcohol. After centrifugation at $755 \mathrm{~g}$ for 10 minutes, the supernatant fluid was again discarded and the precipitate dissolved in $2 \mathrm{ml} \mathrm{20 \%}$ potassium hydroxide. This solution was heated for 30 minutes at $100^{\circ} \mathrm{C}$. The glycogen was then reprecipitated three times with $2.4 \mathrm{ml} 100 \%$ alcohol, after redissolving the glycogen each time in 2 $\mathrm{ml}$ distilled water. Before precipitating for the third time, $0.1 \mathrm{ml} 10 \% \mathrm{Na}_{2} \mathrm{SO}_{4}$ was added to the solution of glycogen. The final precipitate of glycogen was redissolved in $0.5 \mathrm{ml}$ distilled water, and a $0.2-\mathrm{ml}$ sample of this was added to $3.8 \mathrm{ml}$ hydroxide of hyamine and $10 \mathrm{ml}$ $0.4 \%$ diphenyloxazole in toluene. Radioactivity was counted in a liquid scintillation spectrometer with a $54 \%$ efficiency. In each experiment a tube without leukocyte sonicate was included. Results were expressed as counts per minute per $10^{8}$ leukocytes. The validity of this assay is based on the following considerations. Debranching enzyme in vivo splits only those glucose units from glycogen that are linked by 1-6 linkages. In vitro, the enzyme reaction is reversible, and it is on this basis that the assay is based, namely, the incorporation of glucose$\mathrm{C}^{14}$ into glycogen only at these branch points. Thus, the assay depends on a reaction that is the reverse of that which takes place normally in vivo. Using this assay in human liver, Hers has demonstrated that the radioactive glucose is incorporated into glycogen only at branch points (10). If the incorporation of radioactivity into glycogen were proceeding via the uridine diphosphate glucose (UDPG) glycogen synthetase pathway or as a result of phosphorylase activity, the radioactivity in the glycogen should not be restricted to the glucose molecules at the branch points. Although this was not proven in leukocytes in the present study, presumably the enzyme in leukocytes is similar to that in human liver. The present studies do not indicate whether the introduction of radioactive glucose at the branch point results from an exchange reaction or whether there is actual net synthesis of glycogen during the reaction. In vivo, the formation of a branch point is mediated by the enzyme amylo $1-4 \rightarrow$ 1-6 transglucosidase rather than a reversal of the action of debranching enzyme.

Erythrocyte glycogen was measured by a modification of the method of Sidbury, Cornblath, Fisher, and House (13). Ten $\mathrm{ml}$ of heparinized blood was centrifuged in a refrigerated centrifuge for 30 minutes at $2,000 \mathrm{rpm}$. The plasma and buffy coat were then removed, and an equal volume of ice-cold $20 \%$ trichloroacetic acid was added. After mixing, the tubes were sonicated for $\mathbf{5}$ minutes. After centrifugation, glycogen was precipitated

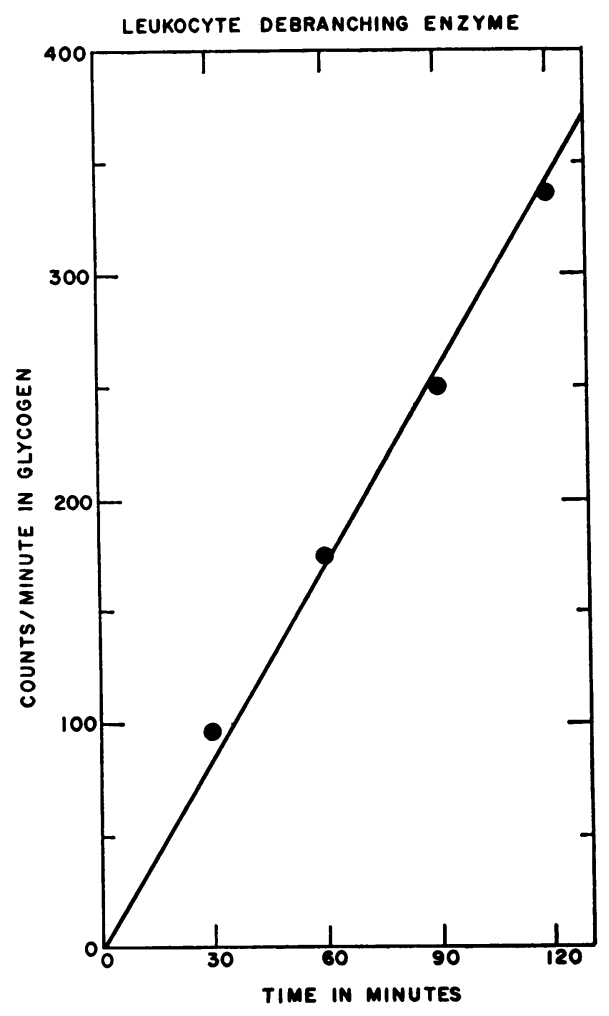

Fig. 1. INCORPORATION OF GLUCOSE-C $C^{14}$ INTO GLYCOGEN BY LEUKOCYTE BRANCHING ENZYME AS A FUNCTION OF TIME. 
TABLE I

Relationship between debranching enzyme activity and number of leukocytes sonicated

\begin{tabular}{ccc}
\hline \hline $\begin{array}{c}\text { Leukocytes } \\
\text { sonicated }\end{array}$ & $\begin{array}{c}\text { Debranching } \\
\text { activity }\end{array}$ & $\begin{array}{c}\text { Debranching } \\
\text { activity in } \\
\text { leukocytes }\end{array}$ \\
\hline$n o$. & $c p m$ & $c p m / 10^{8}$ \\
$.66 \times 10^{7}$ & 169 & 2,580 \\
$1.97 \times 10^{7}$ & 444 & 2,260 \\
$3.93 \times 10^{7}$ & 1,133 & 2,880 \\
\hline
\end{tabular}

in the clear supernatant fluid by the addition of $2.5 \mathrm{vol}$ of absolute ethanol. Leukocyte glycogen was measured as previously reported (11).

\section{RESULTS}

Figure 1 demonstrates the activity of debranching enzyme plotted as a function of time. The enzymatic activity is linear throughout 2 hours of incubation. The data in Table I demonstrate that debranching enzyme activity is proportional to the enzyme concentration expressed as number of leukocytes in the sonicate added. In the leukocyte assays, the average number of leukocytes used was $1.5 \times 10^{7}$ per tube.

Table II summarizes the leukocyte debranching activity in a series of 17 control subjects. The mean activity was $3,158 \pm 125 \mathrm{cpm}$ per $10^{8}$ leukocytes with a range of 2,200 to 4,820 . One normal subject, G.S., studied on three separate oc- casions had activities of 2,590, 2,320, and 2,350. The youngest patient tested was a 9-month-old infant and the oldest, a 45-year-old woman. In general, the differential leukocyte counts in the children revealed a higher percentage of lymphocytes than in the adults, but this did not seem to alter the average enzyme activity, which was 3,050 for the children and 3,190 for the adults. No significant debranching activity was found in erythrocytes, with approximately 1,000 times as many erythrocytes used as the usual number of leukocytes in any one determination.

Table III demonstrates the leukocyte debranching enzyme activity in patient S.P. with Type III glycogenosis and in members of her family. Very little activity was demonstrable in the patient's leukocytes, an average of $121 \mathrm{cpm}$ per $10^{8}$ leukocytes compared to the normal mean activity of 3,158. All members of the patient's family except D.P., Jr., had reduced leukocyte debranching enzyme activity-J.P., 1,555 ; D.P., Sr., 1,070; and K.P., 945. D.P., Jr., had a level of 2,900, which is within the limits of normal. Of interest is the fact that a child with hepatomegaly of unknown cause and four children with types of glycogen storage disease presumably other than the Type III all had normal leukocyte debranching activity (Table II).

Leukocyte and erythrocyte glycogen in the pa-

TABLE II

Leukocyte debranching enzyme activity in control subjects

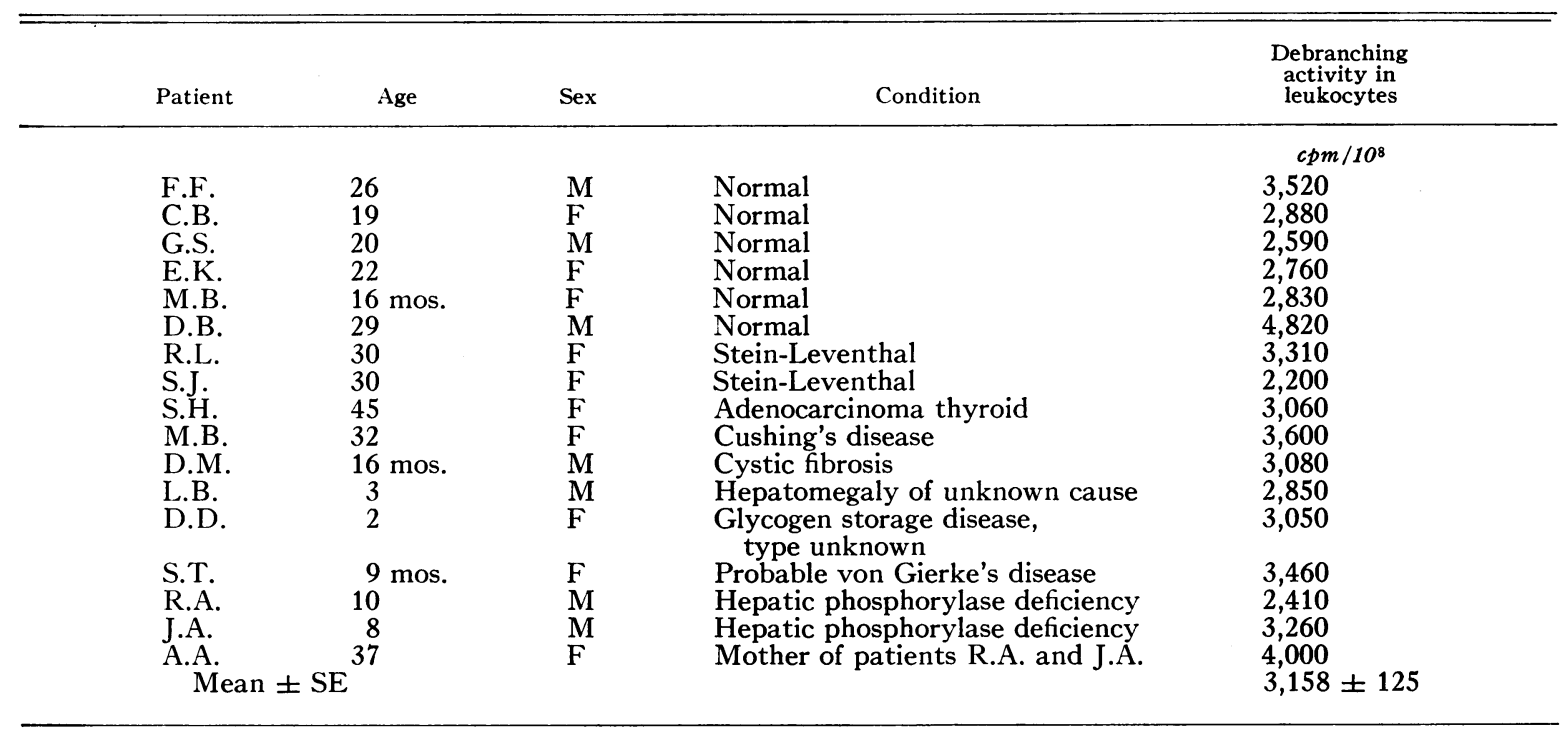


TABLE III

Leukocyte debranching enzyme activity in patient $S . P$. with type III glycogenosis and in her family

\begin{tabular}{|c|c|c|c|}
\hline Patient & Age & Relation & $\begin{array}{l}\text { Debranching activity } \\
\text { in leukocytes }\end{array}$ \\
\hline & & & $c p m / 10^{8}$ \\
\hline S.P. & 3 & Patient & 121 (4) $[0-255]^{*}$ \\
\hline J.P. & 29 & Mother & 1,555 (2) $[1,400-1,710]$ \\
\hline D.P., Sr. & 29 & Father & $1,070(3)[500-1,560]$ \\
\hline K.P. & 5 & Sister & 945 (3) $[618-1,140]$ \\
\hline D.P., Jr. & 16 mos. & Brother & 2,900 (3) $[2,510-3,300]$ \\
\hline \multicolumn{2}{|c|}{ Control mean $\pm S E$} & & $3,158 \pm 125$ \\
\hline
\end{tabular}

* Numbers in parentheses represent number of determinations and numbers in brackets represent the range of values for each patient.

TABLE IV

Leukocyte and erythrocyte glycogen in patient with type III glycogenosis and in her family

\begin{tabular}{lccc}
\hline & & \multicolumn{2}{c}{ Glycogen } \\
\cline { 3 - 4 } Patient & Relation & Leukocytes & Erythrocytes \\
\hline & & $\mu g / 10^{7}$ cells & $\begin{array}{c}\mu g / g \text { hemo- } \\
\text { globin }\end{array}$ \\
& & 30.4 & 19 \\
J.P. & Mother & 29.9 & 43 \\
D.P., Sr. & Father & 21.8 & 84 \\
K.P. & Sister & 10.8 & 52 \\
D.P., Jr. & Brother & 55.4 & 111 \\
S.P. & Patient & $34.3 \pm 0.9[10]^{*}$ & $59 \pm 9[11]^{*}$ \\
Normal mean \pm SE & & $20-38$ & $21-135$ \\
Range & &
\end{tabular}

$*$ Numbers in bracket $s=$ numbers of subjects.

tient and her family is shown in Table IV. Erythrocyte glycogen was within the normal range for all members of the family tested including the patient. The range of normal subjects agrees very well with that previously reported by Sidbury and associates (13). However, leukocyte glycogen was somewhat elevated in the patient S.P., but not in her family members.

When a sample of the sonicated leukocytes from the patient S.P. was added to an equal volume of normal sonicated leukocytes, no inhibition of debranching activity in the normal leukocytes was noted.

\section{DISCUSSION}

The finding of low debranching enzyme in leukocytes from a patient with Type III glycogenosis demonstrates the usefulness of this procedure for the diagnosis of this type of glycogen storage disease. The normal level of this enzyme in leukocytes from patients with Types I (glucose 6-phosphatase), VI (hepatic phosphorylase), and an unknown type of glycogen storage disease indicates the specificity of this finding. However, until all types of glycogen storage disease can be tested, the assay cannot be said to be completely specific. The ease and feasibility of studying leukocytes compared with liver tissue is evident and should facilitate further study of this disease, particularly from the point of view of inheritance and possible effects of medications.

The low levels of this enzyme in leukocytes from both parents are consistent with an autosomal recessive type of inheritance. However, no conclusions can be drawn on the basis of the study of a single family. It is hoped that this report will stimulate similar studies on more families so that meaningful information concerning the genetics of the disease may be obtained. If further investigations do support an autosomal recessive type of inheritance, this will be in contrast to the demonstration of a low level of leukocyte phosphorylase in only one parent of patients with hepatic phosphorylase-deficient glycogen storage disease $(11,14)$.

The normal level of erythrocyte glycogen in the patient studied is in contrast to the findings of Sidbury and associates (13). They have reported that erythrocyte glycogen is markedly elevated in only Type III glycogenosis. Patients with Types I, II, and IV all had normal levels of erythrocyte glycogen. Although there were slight differences in the method for erythrocyte glycogen used in the present study and that used by Sidbury and associates (13), it seems unlikely that these would account for the differences. In their studies, one of the patients with Type III glycogen storage disease had erythrocyte glycogen values that were only $2 \frac{1}{2}$ times normal, whereas the remaining five patients had values that were at least ten times normal (13). The significance of the normal value in our patient is not apparent at the present time. In contrast to the normal level of erythrocyte glycogen in patient S.P.. is the elevated level of leukocyte glycogen. Although Sidbury and associates (13) did not report levels of leukocyte glycogen, these authors did state that 85 to $90 \%$ of blood glycogen is within the leukocyte.

\section{SUMMARY}

Debranching enzyme has been measured in leukocytes from control subjects and from a patient 
with Type III glycogenosis and her family members. The debranching activity was very low in leukocytes from the patient with the disease and was significantly reduced in both her parents and one sibling. In another sibling the level was normal. It is suggested that this assay may be a useful diagnostic test for this disease as well as a means for diagnosing the heterozygote state. The finding of the reduced levels of debranching enzyme in both parents is consistent with an autosomal recessive type inheritance. Leukocyte debranching enzyme was normal in patients with glycogen storage disease of Types I, VI (hepatic phosphorylase deficiency), and an unknown type.

\section{ACKNOWLEDGMENTS}

We acknowledge the kind help and cooperation of Dr. Philip Adler, Dr. Albert DeStefano, Dr. Gerald Powell, and Dr. Paul di Sant'Agnese in studying the patients with glycogen storage disease.

\section{REFERENCES}

1. Cori, G. T., and C. F. Cori. Glucose 6-phosphatase of the liver in glycogen storage disease. J. biol. Chem. 1952, 199, 661.

2. Di Sant'Agnese, P. A. Diseases of glycogen storage with special reference to the cardiac type of generalized glycogenosis. Ann. N. Y. Acad. Sci. 1959, $72,439$.

3. Hers, H. G. Recent developments in the biochemistry of glycogen storage disease and of fructose intolerance. Chem. Weekblad 1961, 33, 57.
4. Illingworth, B. Glycogen storage disease. Amer. J. clin. Nutr. 1961, 9, 683.

5. Pompe, J. C. Over idiopatische hypertrophic van het hart. Ned. T. Geneesk. 1932, 76, 304.

6. Illingworth, B., and G. T. Cori. Structure of glycogens and amylopectins III. Normal and abnormal human glycogen. J. biol. Chem. 1952, 199, 653.

7. Andersen, D. H. Familial cirrhosis of the liver with storage of abnormal glycogen. Lab. Invest. 1956, $5,11$.

8. Mommaerts, W. F. H. M., B. Illingworth, C. M. Pearson, R. J. Guillory, and K. Seraydarian. A functional disorder of muscle associated with the absence of phosphorylase. Proc. nat. Acad. Sci. (Wash.) 1959, 45, 791.

9. Schmid, R., P. W. Robbins, and R. R. Traut. Glycogen synthesis in muscle lacking phosphorylase. Proc. nat. Acad. Sci. (Wash.) 1959, 45, 1236.

10. Hers, H. G. Etudes enzymatiques sur fragments hépatiques; application à la classification des glycogenosis. Rev. int. Hépat. 1959, 9, 35.

11. Williams, H. E., and J. B. Field. Low leukocyte phosphorylase in hepatic phosphorylase-deficient glycogen storage disease. J. clin. Invest. 1961, 40, 1841.

12. Skoog, W. A., and W. S. Beck. Studies on the fibrinogen, dextran and phytohemagglutinin methods of isolating leukocytes. Blood 1956, 11, 436.

13. Sidbury, J. B., Jr., M. Cornblath, J. Fisher, and E. House. Glycogen in erythrocytes of patients with glycogen storage disease. Pediatrics 1961, 27, 103.

14. Hülsmann, W. C., T. L. Oei, and S. Van Creveld. Phosphorylase activity in leukocytes from patients with glycogen-storage disease. Lancet 1961, 2, 581. 